\title{
Optimized Nitrogen Application Increases Soil Water Extraction by Changing in-Season Maize Root Morphology and Distribution in Rainfed Farmland
}

\author{
Liang Tang ${ }^{1,2}$, Haoran Sun ${ }^{1,2}$, Ruxiao Sun ${ }^{1,2}$, Yinan Niu ${ }^{1,2}$, Jingrong Song ${ }^{1,2}$, Shiqing $\mathrm{Li}^{1,2, *}$ \\ and Yufang Shen 1,2 \\ 1 State Key Laboratory of Soil Erosion and Dryland Farming on the Loess Plateau, Northwest A\&F University, \\ Yangling 712100, Shaanxi, China; tangliang0311@163.com (L.T.); sunhaoranmail@163.com (H.S.); \\ 18443176162@163.com (R.S.); 15513998120@163.com (Y.N.); jrsong2263@163.com (J.S.); \\ shenyufang@nwafu.edu.cn (Y.S.) \\ 2 College of Natural Resources and Environment, Northwest A\&F University, Yangling 712100, Shaanxi, China \\ * Correspondence: sqli@ms.iswc.ac.cn; Tel.: +86-139-0922-2988
}

Received: 30 September 2020; Accepted: 17 October 2020; Published: 20 October 2020

\begin{abstract}
The proper promotion of a deep root system is important for maize cultivation to improve water use efficiency in the arid and semi-arid Loess Plateau. Here, a field experiment was conducted to assess the effect of combined controlled release urea and normal urea on root growth and water extraction of maize in dryland fields. Maize in the combined controlled release urea and normal urea treatment had greater root systems compared to those in the normal urea treatment and no N application treatment. Compared to the urea treatment, combined controlled release urea and normal urea advanced the root length density and root weight density in the $0-10 \mathrm{~cm}$ soil layer at R1 stage by $30.99 \%$ and $45.03 \%$ in 2016 and by $20.54 \%$ and $19.13 \%$ in 2017 . The root length density also increased at the dent stage (R5) by 52.05\% and 47.75\% in 2016 and 2017, and root weight density increased by $19.58 \%$ in 2016 . Combined controlled release urea and normal urea promoted production of fine roots and root distribution, as well as decreased soil water storage (SWS) in the deep soil layer at the R5 stage. The grain yield was positively correlated with root length density and root weight density in the topsoil layer at the silking stage (R1) and in the whole soil profile at the R5 stage, suggesting that better root system management is helpful for increasing crop grain yield. Therefore, this work demonstrates that combined use of controlled release urea and normal urea to higher crop yields might attribute to increasing water extraction by optimizing in-season maize root morphology and distribution in the rainfed farmland of the Loess Plateau.
\end{abstract}

Keywords: controlled release urea; root length density; root weight density; average root diameter; soil water storage

\section{Introduction}

Maize grain production must increase by $1.3 \%$ per year until 2025 to meet the demands of the increasing global human population, as it is expected to increase by two to three billion by 2050 [1]. The application of nitrogen $(\mathrm{N})$ fertilizer is one of the main methods to improve crop production [2]. However, the excessive use of $\mathrm{N}$ fertilizer has no positive effect on yield [2] and causes a large amount of undesirable nitrate residual pollution, air pollution with emissions of $\mathrm{N}_{2} \mathrm{O}$ and $\mathrm{NH}_{3}$, food security issues, and threats to land health [3-5]. Therefore, modern agriculture should consider both high yield and environmental sustainability. Studies have shown that reducing the time of organic $\mathrm{N}$ is in soil solution before crop absorption can reduce the risk of $\mathrm{N}$ loss and increase $\mathrm{N}$ use efficiency (NUE) which is defined as the ratio of grain yield and the amount of N applied [6]. For that reason, 
topdressing was adopted as a main traditional method to synchronize the $\mathrm{N}$ demand of crop and reduce retention time over the past few decades [7] in the dryland grain production region of Northwest China. Previous studies have reported that applying $\mathrm{N}$ with three splits significantly increased grain yields with 14.3 and $14.8 \mathrm{~kg} \mathrm{ha}^{-1}$ compared to applying $\mathrm{N}$ for one time at sowing which increased grain yields by only 12.8 and $13.5 \mathrm{~kg} \mathrm{ha}^{-1}$ in the two experimental years [8]. However, this $\mathrm{N}$ practice is time consuming and laborious. Therefore, a method that both improves NUE and saves labor should be further probed to achieve sustainable production in agriculture.

In recent years, controlled release urea with one-off application has been partially adopted as optimal N management to improve NUE and save labor. It is better than the slow-release urea that can control the rate that $\mathrm{N}$ is released into the soil solution to synchronize it with crop $\mathrm{N}$ requirements [9] and increase crop production in China and worldwide [10,11]. However, the controlled release urea has been considered too expensive to use in cereal crops in developing countries [12], and the release rate of controlled release urea is affected by temperature and moisture [13]. Therefore, combined controlled release urea and normal urea has been accepted for many crops [14,15]. A study conducted in Italy reported that mixed controlled release urea and urea at atio of 1:1 and 3:1 increased bermudagrass forage production by $10.0 \%$ and $6.1 \%$ relative to the untreated urea treatment [15]. A study conducted in Northeast China reported that combined controlled release urea and normal urea at a ratio of 7:3 increased the maize grain yield by 9.1-21.0\% compared to normal urea treatment [16]. A study conducted in Northwest China reported that combined controlled release urea and normal urea at a ratio of 1:2 increased grain yields and nutrient efficiency compared to when solely urea was applied [17]. Therefore, it is very important to adjust the fertilization ratio of controlled release urea according to crop and climate characteristics.

Knowledge of root spatial distribution is essential to study the potential of crops to absorb water and nutrients and obtain ideal crop yields in rainfed farming, especially in the arid and semi-arid Loess Plateau of China. In general, root growth is genetically controlled [18], but root morphology is highly plastic [19] and affected by many factors such as water, nutrients, and plant density [20-22]. $\mathrm{N}$ deficiency induces root foraging behavior and stimulates deeper root growth to absorb water and $\mathrm{N}$ [23]. However, the excessive application of $\mathrm{N}$ fertilizer reduces root biomass [24] and the proportion of the root system in deeper soil layers [25]. The long-term use of urea improves nutrient levels in the topsoil and results in root concentration mainly in the topsoil layer [26]. Until now, few studies have focused on the effect of controlled release urea on crop roots. According to a previous study in Mozambique, maize root growth showed a clear tendency for higher root density in semi-arid loamy sandy soil with slow-release urea as a topdressing $\mathrm{N}$ fertilizer, compared to when quick-release urea was used as a topdressing $\mathrm{N}$ fertilizer [21]. This implies that crop rooting systems may vary with optimized application of controlled release fertilizer. However, how roots respond to combined controlled release urea and normal urea and the mechanism by which they affect root systems of crop production in arid and semi-arid areas remains unclear and requires further study. An improved understanding of root-growth response will provide a theoretical basis for the application and popularization of controlled release fertilizer in maize.

Therefore, a two year field experiment was designed and conducted to focus on the effect of optimal mixture of controlled release urea and normal urea on root growth and water extraction of maize in the arid and semi-arid region. For this, we characterized temporal and spatial distribution patterns of spring maize roots and soil water storage in the later growth period of maize. We also evaluated the correlation between root length density (RLD) and root weight density (RWD) over various soil depths and grain yield at different maize growth stages. The study provided the related mechanism of rational application of controlled release fertilizer on increased crop yield in the semiarid Loess Plateau area. 


\section{Materials and Methods}

\subsection{Experimental Site}

The field experiment was conducted during the 2016 and 2017 growing seasons at Changwu Research Station of Agriculture and Ecology, which is located in a typical rainfed farming area on the Loess Plateau in China (Figure 1). Precipitation during the two maize growing seasons (from April to September) was 390 and $372 \mathrm{~mm}$, respectively (Figure 2). The soil was classified as Cumuli Haplustolls according to the American soil taxonomy system. Samples from the top $20 \mathrm{~cm}$ of soil were taken from the experimental field before sowing in 2016 to analyze the basic physicochemical properties. The soil contained $14.67 \mathrm{~g} \mathrm{~kg}^{-1}$ soil organic matter, $0.94 \mathrm{~g} \mathrm{~kg}^{-1}$ total $\mathrm{N}, 7.6 \mathrm{mg} \mathrm{kg}^{-1}$ mineral $\mathrm{N}$ (total as $\mathrm{NO}_{3}^{-}-\mathrm{N}^{-}$ and $\mathrm{NH}_{4}{ }^{+}-\mathrm{N}$ ), $15.4 \mathrm{mg} \mathrm{kg}^{-1}$ available phosphorus, $145.5 \mathrm{mg} \mathrm{kg}^{-1}$ available potassium and the soil $\mathrm{PH}$ was 7.8. As the Loess parent material is loose with uneven topography, the soil water erosion and nutrient loss may take place due to uneven annual precipitation which can result in poor soil [27].

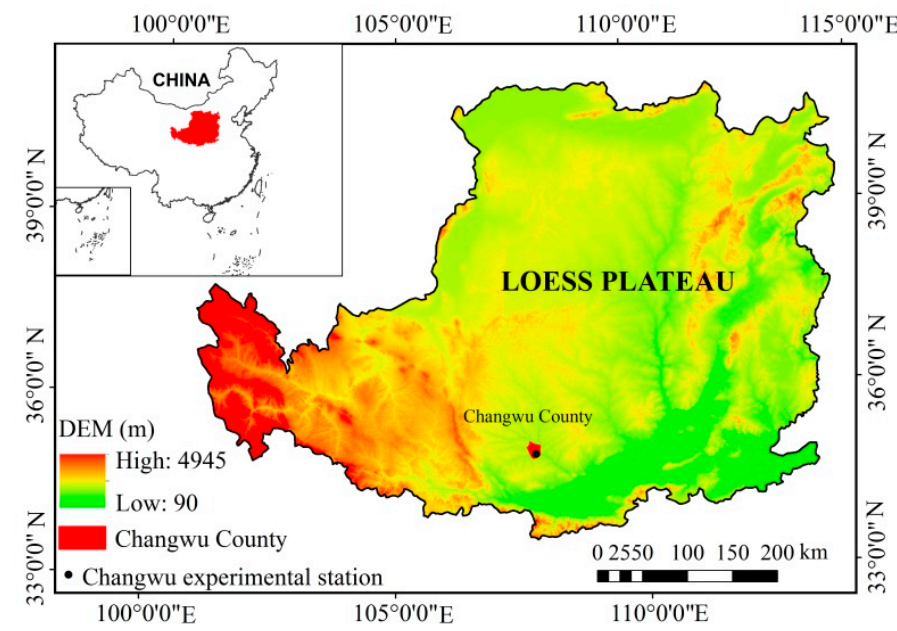

Figure 1. Location of the Loess Plateau and the Changwu Research Station of Agriculture and Ecology.

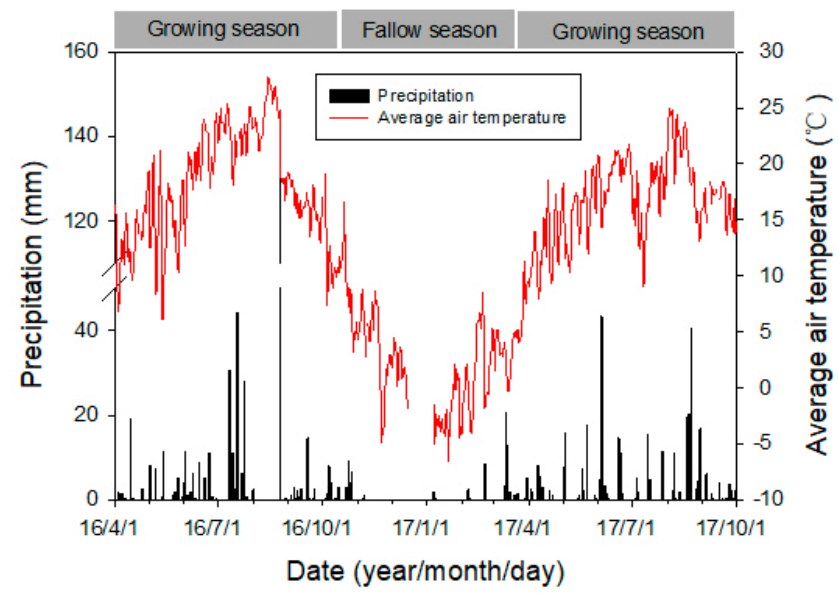

Figure 2. Daily precipitation and average air temperature during field experiments. The black columns represent precipitation and the red line represents average air temperature.

\subsection{Experimental Design}

The field experiment was set up with three different $\mathrm{N}$ application treatments as follows: no $\mathrm{N}$ application (N0), normal urea alone (NU), and optimized nitrogen application with controlled release urea and normal urea mixture at a 1:2 ratio ( $\mathrm{N}$ from controlled release urea: $\mathrm{N}$ from normal urea) 
(NC). The total amount of $\mathrm{N}$ applied in the NC and NU treatments was $225 \mathrm{~kg} \mathrm{~N} \mathrm{ha}^{-1}$. Each plot had an area of $63 \mathrm{~m}^{2}(7 \mathrm{~m} \times 9 \mathrm{~m})$ and was laid out as a randomized block design with four replicates per treatment. In the NC treatment, controlled release urea and normal urea were applied as a basal fertilizer in just one application before planting. In the NU treatment, normal urea was applied as a split application, with $40 \%$ of the total $\mathrm{N}$ applied as a basal fertilizer before planting and $30 \%$ as a supplemental fertilizer at the jointing and silking stages. The normal urea used in this experiment contains $46 \% \mathrm{~N}$. The controlled release urea used in this experiment was a polymer coated urea coating 44\% N and manufactured by Agrium Inc., Calgary, AB, Canada (Environmentally Smart Nitrogen [ESN]). The cumulative release rate in the controlled release urea was $80 \%$ at 60 days when the temperature was $25^{\circ} \mathrm{C}$. To each plot, $\mathrm{P}\left(40 \mathrm{~kg} \mathrm{ha}^{-1}\right)$ and $\mathrm{K}\left(80 \mathrm{~kg} \mathrm{ha}^{-1}\right)$ fertilizers were applied as a basal fertilizer. All basal fertilizers were uniformly distributed over the soil surface by hand and then plowed into the soil at a depth of $15-20 \mathrm{~cm}$ by rotary tillage.

Maize was seeded at a depth of $5 \mathrm{~cm}$ on 24 April 2016 and 26 April 2017 with hand planters to a stand of 65,000 plants per hectare with intra-rows of $30 \mathrm{~cm}$ and an alternating wide and narrow row spacing of $60 \mathrm{~cm}$ and $40 \mathrm{~cm}$, respectively. The plastic film used in this study was $0.008 \mathrm{~mm}$ thick white polyethylene. Holes were made in the trench every $30 \mathrm{~cm}$ to allow infiltration. There was no irrigation, and natural rainfall was the only source of water over the entire maize growing season. The standard system maize growth period was used to identify the crop growth period [28].

\subsection{Sampling and Analyses}

Roots were collected from the N0, NC, and NU treatments in 2016 and 2017. A monolith method [29] was employed to study the spatial distribution of the root system in the soil profiles. A soil block centered on consecutive two harvest plants with a length of $60 \mathrm{~cm}$ and a width of $50 \mathrm{~cm}$ was excavated to a depth of $60 \mathrm{~cm}$ at the six leaf stage (V6) and to a depth of $100 \mathrm{~cm}$ at silking stage (R1), milk stage (R3), and dent stage (R5). The soil block was divided into seven (five in V6 stage) depth intervals: 0-10, 10-20, 20-30, 30-40, 40-60, 60-80, and 80-100 cm. Each soil layer was divided into 30 cubes at $10 \mathrm{~cm}$ inter-row and $10 \mathrm{~cm}$ intra-row intervals. There were four repeats for harvesting roots in each treatment in this study. All of the visible roots in each cube were picked out by hand and packed individually. These roots were then washed using running water and frozen at $-20^{\circ} \mathrm{C}$ until they were scanned in grey-scale mode at 300 dpi (Epson V800, Suwa, Japan). All images were analyzed with WinRhizo Provision 5.0 software (Regent Instruments Inc., Quebec, Canada) to obtain root growth parameters, and then the root was oven dried at $80{ }^{\circ} \mathrm{C}$ for $48 \mathrm{~h}$ to obtain the root dry weight. The root length and root weight in each soil cube were added together to calculate the total root length and root weight in one soil layer and in the whole soil profile (0-60 or 0-100 cm soil profile). The root weight density ( $R W D, \mathrm{~g} \mathrm{~m}^{-3}$ ) and root length density ( $\mathrm{RLD}, \mathrm{cm} \mathrm{cm}^{-3}$ ) were calculated based on the following equations [30]:

$$
\begin{gathered}
\mathrm{RWD}=\mathrm{M} \div \mathrm{V} \times 10^{6} \\
\mathrm{RLD}=\mathrm{L} \div \mathrm{V}
\end{gathered}
$$

where M is the root weight $(\mathrm{g}), \mathrm{L}$ is the root length $(\mathrm{cm})$, and V is the volume of the soil sample $\left(\mathrm{cm}^{3}\right)$.

At the R5 stage, an auger was used to collect soil samples at $20 \mathrm{~cm}$ intervals in the $0-200 \mathrm{~cm}$ soil profile. All the soil samples were weighed immediately and oven dried at $105{ }^{\circ} \mathrm{C}$ for $24 \mathrm{~h}$ until a consistent weight was achieved to determine the soil water content (gravimetric water content, $\% \mathrm{~g} \mathrm{~g}^{-1}$ ). The soil water storage (SWS) in each soil layer at the R5 stage was calculated based on the following equation:

$$
\mathrm{SWS}=\mathrm{H} \times \mathrm{P} \times \mathrm{S} \times 10
$$

where $\mathrm{H}$ is the soil depth $(\mathrm{cm}), \mathrm{P}$ is the soil bulk density $\left(\mathrm{g} \mathrm{cm}^{-3}\right)$, and $\mathrm{S}$ is the soil water content $(\%)$ in each soil layer. 
At harvest, an area of $10 \mathrm{~m}^{2}$ in each plot was manually harvested. It was first dried at $105^{\circ} \mathrm{C}$ for $30 \mathrm{~min}$ and then oven dried to a constant weight at $75^{\circ} \mathrm{C}$. Using the standard moisture for maize grain as a reference, the maize grain yield in this experiment was calculated at $15.5 \%$ moisture content [31].

\subsection{Statistical Analyses}

A two-way analysis of variance (ANOVA) was used to evaluate the changes in RLD and RWD with sampling years and $\mathrm{N}$ application treatments as two fixed factors. Pearson correlations were used to analyze the relationship between root parameters (root length density and root weight density) over various soil depths with different growth stages and maize grain yields. Least significant difference testing at a level of 0.05 was used to test the significance of differences. SPSS 18.0 (SPSS Inc., Chicago, IL, USA) and SigmaPlot 12.5 (Systat Software Inc., San Jose, CA, USA) were used to perform all statistical analyses and data plotting.

\section{Results}

\subsection{Root Length Density and Its Distribution in Different Soil Layers}

The root length density (RLD) in the three treatments declined with increasing soil depth and the root system was mainly distributed in the $0-40-\mathrm{cm}$ soil layer (Figure 3). At the R1 stage, the RLD for treatment NC was significantly higher than those for treatments N0 and NU by $128.4 \%$ and $31.0 \%$, respectively, in 2016, and by $134.3 \%$ and $20.5 \%$ in 2017 . At the R5 stage, the RLD for treatment NC was significantly higher than that for treatment NU by $52.1 \%, 66.2 \%, 74.2 \%, 113.5 \%, 97.3 \%, 68.1 \%$, and $119.4 \%$ in the $0-10,10-20,20-30,30-40,40-60,60-80$, and 80-100-cm soil layer in 2016, and by $47.8 \%, 24.2 \%, 63.2 \%$, and $51.4 \%$ in the $0-10,10-20,60-80$, and 80-100-cm soil layer in 2017.

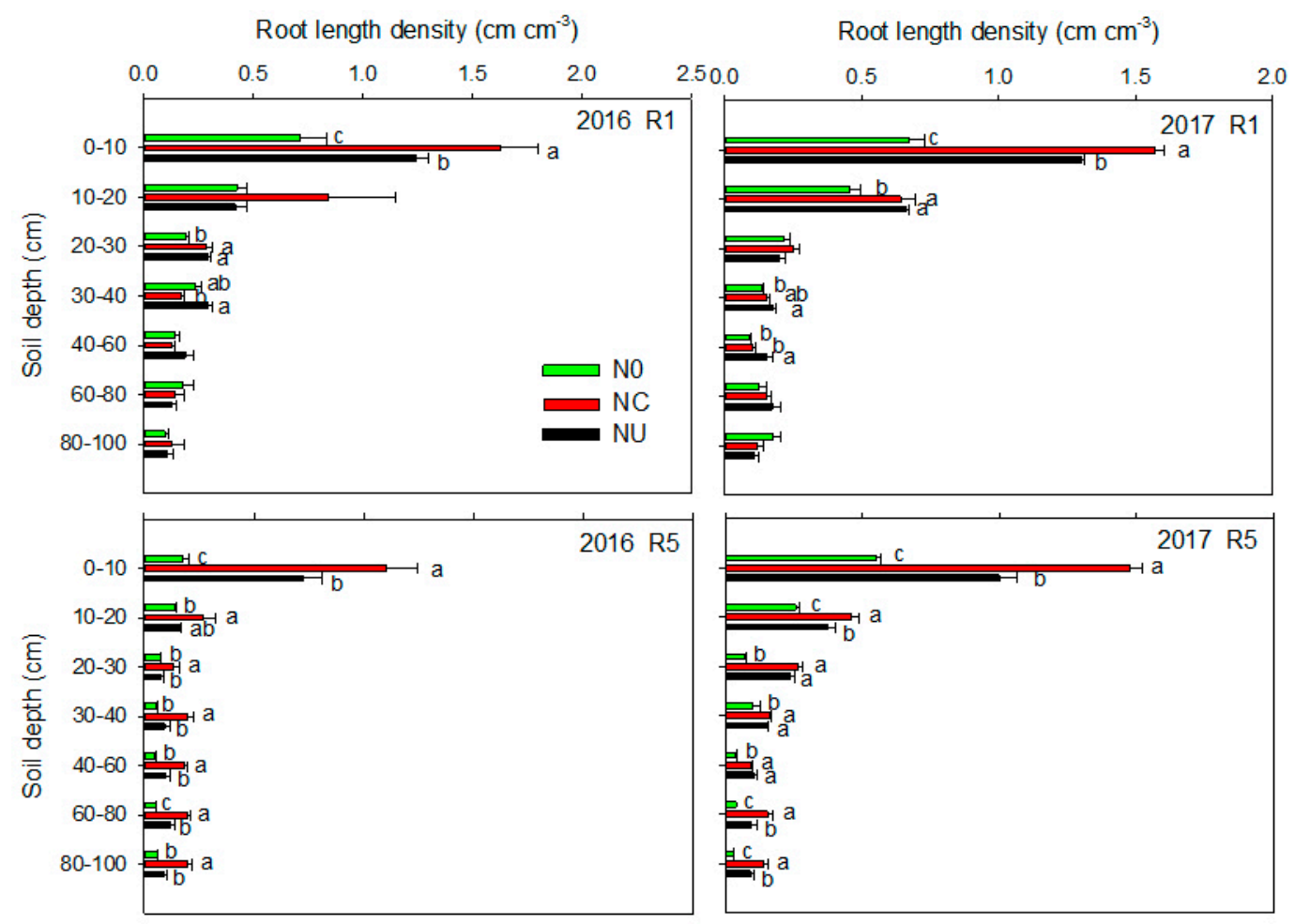

Figure 3. Root length density in the $0-100 \mathrm{~cm}$ soil layers with the three treatments in 2016 and 2017 as follows: no $\mathrm{N}$ application (N0), combined controlled release urea and normal urea at a ratio of 1:2 (NC), and normal urea alone (NU). Letters on the graph show significant differences at $p<0.05$. 
The total RLD in the whole soil profile increased rapidly from V6 to the R1 stage and decreased slowly until the R5 stage (Table 1). In 2016, the total RLD for NC treatment at the V6 stage was significantly lower than that for NU treatment. However, the total RLD for NC treatment at the R5 stage was significantly higher than those for N0 and NU treatments. In 2017, there was no difference among treatments at the V6 stage. However, the total RLD for NC treatment at the R3 and R5 stages was significantly higher than those for N0 and NU treatments. The ANOVA indicated that sampling years and treatments had significant effect $(p<0.05)$ on total RLD at the R3 and R5 stages.

Table 1. Effects of $\mathrm{N}$ application treatments on total root length density $\left(\mathrm{cm} \mathrm{cm}^{-3}\right)$ in 0-60 (at six leaf stage (V6)) and 0-100 cm (at silking stage (R1), milking stage (R3), and dent stage (R5)) soil layers during the entire growing season in 2016 and 2017.

\begin{tabular}{cccccc}
\hline Year & Treatment & V6 & R1 & R3 & R5 \\
\hline \multirow{2}{*}{2016} & N0 & $0.19 \mathrm{~b}$ & $0.24 \mathrm{~b}$ & $0.13 \mathrm{~b}$ & $0.08 \mathrm{c}$ \\
& NC & $0.20 \mathrm{~b}$ & $0.38 \mathrm{a}$ & $0.32 \mathrm{a}$ & $0.29 \mathrm{a}$ \\
$\mathrm{NU}$ & $0.26 \mathrm{a}$ & $0.31 \mathrm{ab}$ & $0.29 \mathrm{a}$ & $0.17 \mathrm{~b}$ \\
\hline \multirow{2}{*}{2017} & $\mathrm{~N} 0$ & $0.21 \mathrm{a}$ & $0.23 \mathrm{~b}$ & $0.17 \mathrm{c}$ & $0.12 \mathrm{c}$ \\
& $\mathrm{NC}$ & $0.18 \mathrm{a}$ & $0.34 \mathrm{a}$ & $0.35 \mathrm{a}$ & $0.32 \mathrm{a}$ \\
\multicolumn{2}{c}{ Source of variation } & $0.20 \mathrm{a}$ & $0.32 \mathrm{a}$ & $0.28 \mathrm{~b}$ & $0.24 \mathrm{~b}$ \\
\multicolumn{2}{c}{ Year (Y) } & & & & \\
\multicolumn{2}{c}{ Treatments (T) } & $\mathrm{ns}$ & $\mathrm{ns}$ & $*$ & $* * *$ \\
\multicolumn{2}{c}{$\mathrm{Y} \times \mathrm{T}$} & $\mathrm{ns}$ & $* *$ & $* * *$ & ns \\
\hline
\end{tabular}

N0: no $\mathrm{N}$ application, NC: combined controlled release urea and normal urea at a ratio of 1:2, NU: normal urea alone. Numbers in each column in the same sampling year followed by different letters indicate significant $(p<0.05)$ differences between treatments. ns, not significant; * significant at $p<0.05$; ${ }^{* *}$ significant at $p<0.01$; ${ }^{* *}$ significant at $p<0.001$.

\subsection{Root Weight Density and Its Distribution in Different Soil Layers}

Root weight density (RWD) in the three treatments declined with increasing soil depth (Figure 4). At the R1 stage, the RWD for NC treatment was significantly higher than those for N0 and NU treatments in the $0-10 \mathrm{~cm}$ soil layer by $104.8 \%$ and $22.7 \%$, respectively, in 2016 , and by $137.7 \%$ and $19.1 \%$ in 2017. At the R5 stage, the RWD for NC treatment was obviously higher than that for NU treatment by $19.6 \%, 42.8 \%$, and $60.1 \%$ in the $0-10,40-60$, and $80-100 \mathrm{~cm}$ soil layer in 2016 , and by $23.6 \%$, $48.3 \%$ and $46.7 \%$ in the 10-20, 60-80 and 80-100 cm soil layer in 2017. The RWD for NC treatment was significantly higher than that for N0 treatment in the whole soil profile at the R5 stage in both years.

The total RWD in the whole soil profile increased rapidly from the V6 to R1 stage and decreased slowly until the R5 stage (Table 2). In 2016, the total RWD for NC treatment was significantly higher than those for N0 and NU treatments by $72.8 \%$ and $20.1 \%$ at the R1 stage, $148.4 \%$ and $19.4 \%$ at R3, and $139.1 \%$ and $15.2 \%$ at the R5 stage. In 2017, the RWD for NC treatment was significantly higher than those for N0 and NU treatments by $103.5 \%$ and 13.3\% at the R3 stage in 2017. The ANOVA indicated that sampling years and treatments had a significant effect $(p<0.05)$ on total RWD in the whole maize growth stages. 


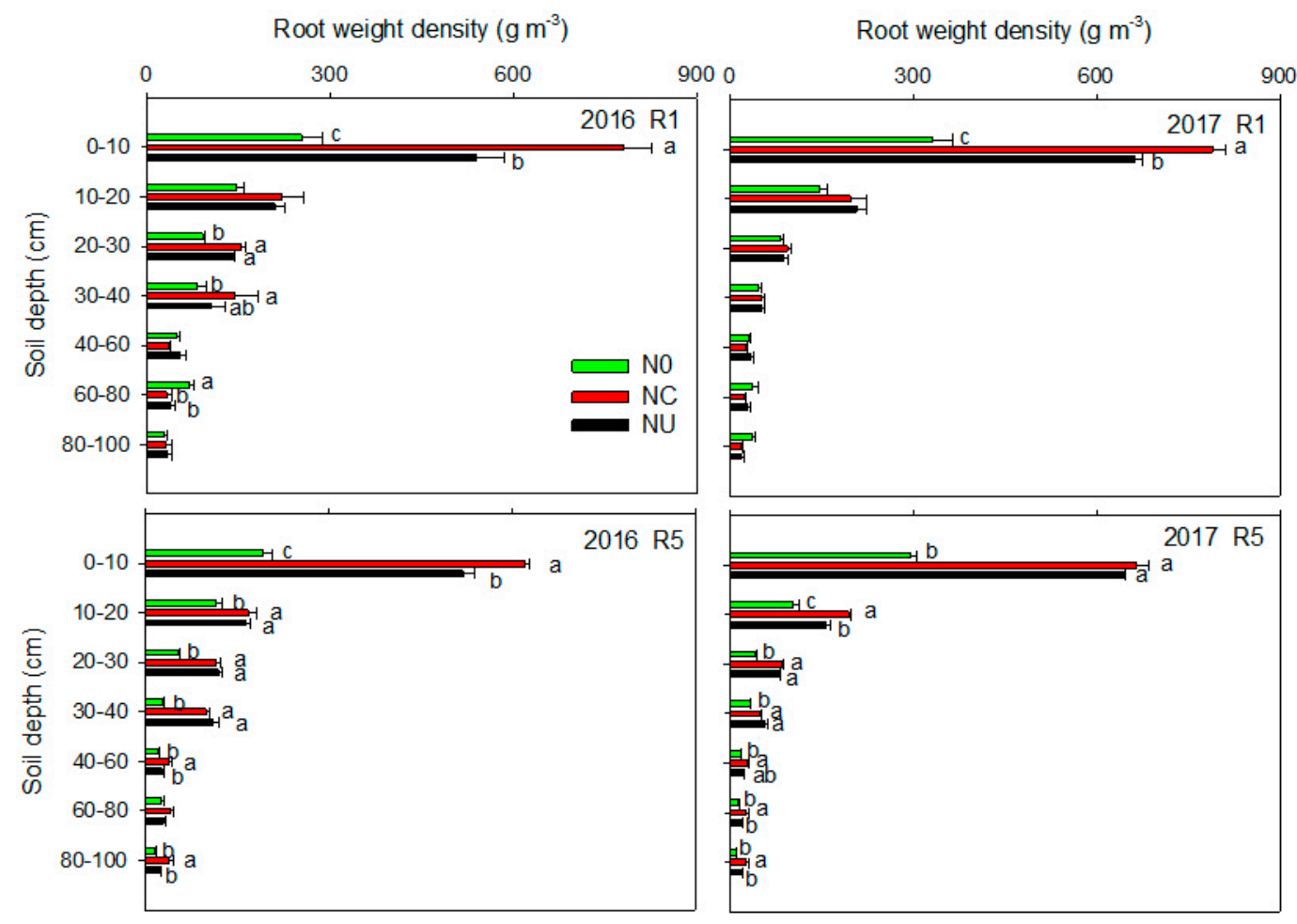

Figure 4. Root weight density in the $0-100 \mathrm{~cm}$ soil layers in the three treatments in 2016 and 2017 as follows: no N application (N0), combined controlled release urea and normal urea at a ratio of 1:2 (NC), and normal urea alone (NU). Letters on the graph show significant difference at $p<0.05$.

Table 2. Effects of $\mathrm{N}$ application treatments on total root weight density $\left(\mathrm{g} \mathrm{m}^{-3}\right)$ in $0-60 \mathrm{~cm}$ (at V6 stage) and 0-100 cm (at R1, R3, and R5 stages) soil layers during the entire growing season in 2016 and 2017.

\begin{tabular}{|c|c|c|c|c|c|}
\hline Year & Treatment & V6 & R1 & R3 & R5 \\
\hline \multirow{3}{*}{2016} & No & $33.3 \mathrm{~b}$ & $86.9 \mathrm{c}$ & $57.9 \mathrm{c}$ & $52.3 \mathrm{c}$ \\
\hline & $\mathrm{NC}$ & $40.8 \mathrm{a}$ & $150.1 \mathrm{a}$ & $143.7 \mathrm{a}$ & $125.0 \mathrm{a}$ \\
\hline & $\mathrm{NU}$ & $37.9 \mathrm{ab}$ & $125.0 \mathrm{~b}$ & $120.4 \mathrm{~b}$ & $108.5 \mathrm{~b}$ \\
\hline \multirow{3}{*}{2017} & No & $52.6 \mathrm{~b}$ & $82.0 \mathrm{~b}$ & $61.5 c$ & $55.5 \mathrm{~b}$ \\
\hline & $\mathrm{NC}$ & $62.7 \mathrm{a}$ & $127.2 \mathrm{a}$ & $125.2 \mathrm{a}$ & $115.7 \mathrm{a}$ \\
\hline & NU & $58.2 \mathrm{ab}$ & 117.8 a & $110.4 \mathrm{~b}$ & $105.6 \mathrm{a}$ \\
\hline \multicolumn{6}{|c|}{ Source of variation } \\
\hline \multicolumn{2}{|c|}{ Year $(\mathrm{Y})$} & $* * *$ & $* *$ & $* * *$ & ns \\
\hline \multicolumn{2}{|c|}{ Treatments $(\mathrm{T})$} & $* *$ & $* * *$ & $* * *$ & $* * *$ \\
\hline \multicolumn{2}{|c|}{$\mathrm{Y} \times \mathrm{T}$} & ns & ns & $* *$ & ns \\
\hline
\end{tabular}

N0: no N application, NC: combined controlled release urea and normal urea at a ratio of 1:2, NU: normal urea alone. Numbers in each column in the same sampling year followed by different letters indicate significant $(p<0.05)$ differences between treatments. ns, not significant; ${ }^{* *}$ significant at $p<0.01 ; * * *$ significant at $p<0.001$.

\subsection{Root Diameter}

Average root diameter (ARD) was classified based on percentage composition (Figure 5). ARD $<0.5 \mathrm{~mm}$ was much more common in the three treatments at both R1 and R5 stages. There was no significant difference among treatments on the ARD in the R1 stage in 2016 and 2017. However, the percentage of ARD $<0.5 \mathrm{~mm}$ for NC treatment was significantly higher than those for N0 and NU treatments by $16.5 \%$ and $7.6 \%$, respectively, in 2016 , and by $4.8 \%$ and $6.5 \%$ in 2017 . 

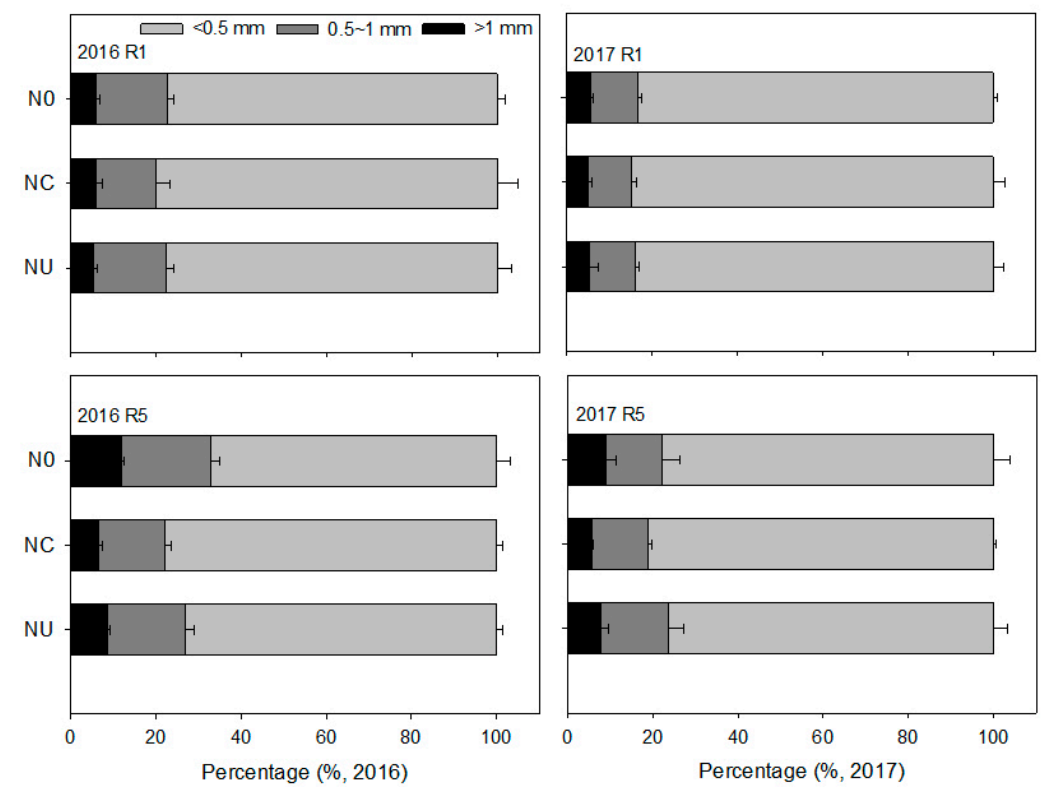

Figure 5. Average root diameter classes as affected by different $\mathrm{N}$ application treatments at $\mathrm{R} 1$ and R5 stages in 2016 and 2017 as follows: no N application (N0), combined controlled release urea and normal urea at a ratio of 1:2 (NC), and normal urea alone (NU).

\subsection{Soil Water and Its Relationship with Root Length Density}

Soil water storage (SWS) at the R5 stage is shown in Figure 6. The N0 treatment had the highest SWS in both years. The SWS was lower with NC treatment than that with NU treatment through the entire soil profiles (except 100-140 cm soil layer) in 2016 and at the 160-200 cm soil layer in 2017. Significant $(p<0.001)$ negative correlations were found between SWS and RLD in the $0-2 \mathrm{~m}$ soil profiles in both experimental years (Figure 7).

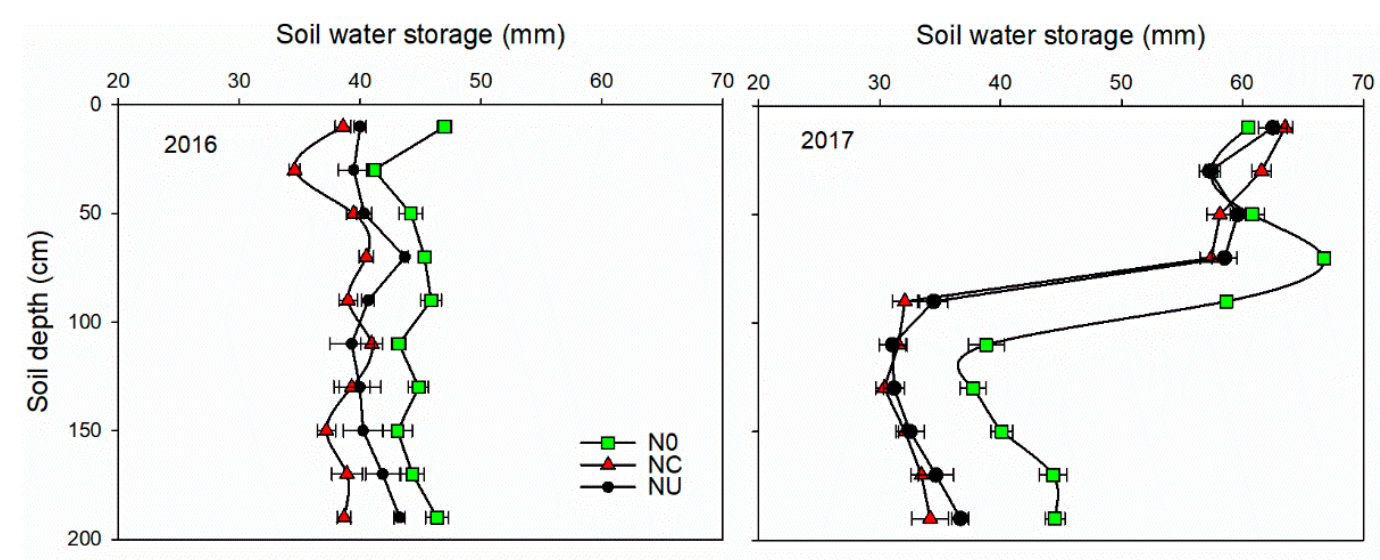

Figure 6. Soil water storage with three treatments at the R5 stage in 2016 and 2017 as follows: no N application (N0), combined controlled release urea and normal urea at a ratio of 1:2 (NC), and normal urea alone (NU). 

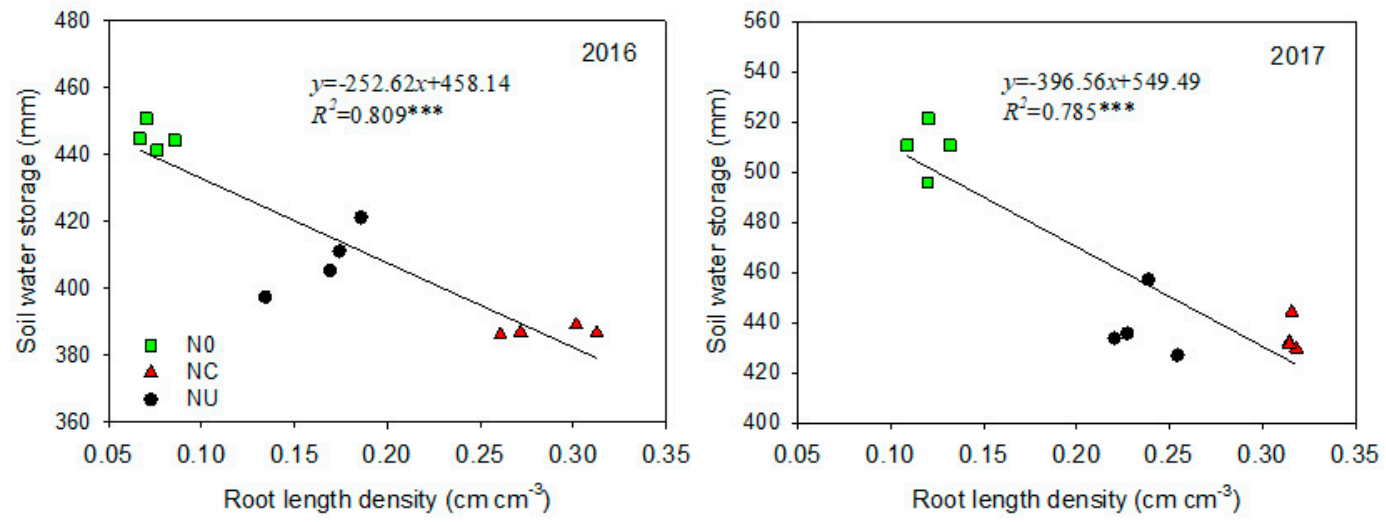

Figure 7. Relationship between root length density and soil water storage with the three treatments in 2016 and 2017 as follows: no N application (N0), combined controlled release urea and normal urea at a ratio of 1:2 (NC), and normal urea alone (NU) at the R5 stage. ${ }^{* * *}$ significant at $p<0.001$.

\subsection{Root to Shoot Ratio}

The root to shoot ratio (R/S) is an important parameter to estimate the distribution of dry biomass between roots and shoots. The V6 stage had the highest R/S values, which decreased rapidly from the V6 to the R1 stage and then decreased gradually with the growth and development of the spring maize (Figure 8). At the R1 stage, the R/S for NC treatment was lower than that for NU treatment by $10.0 \%$ in 2017. At the R3 stage, the R/S for NC treatment was lower than that for NU treatment by $12.9 \%$ and 14.3\%, respectively, in 2016 and 2017. At R5 stage, the R/S for NC treatment was lower than that for NU treatment by $10.0 \%$ and $20.0 \%$, respectively, in 2016 and 2017. The R/S for NC and NU treatments was lower than that for N0 treatment in both years.
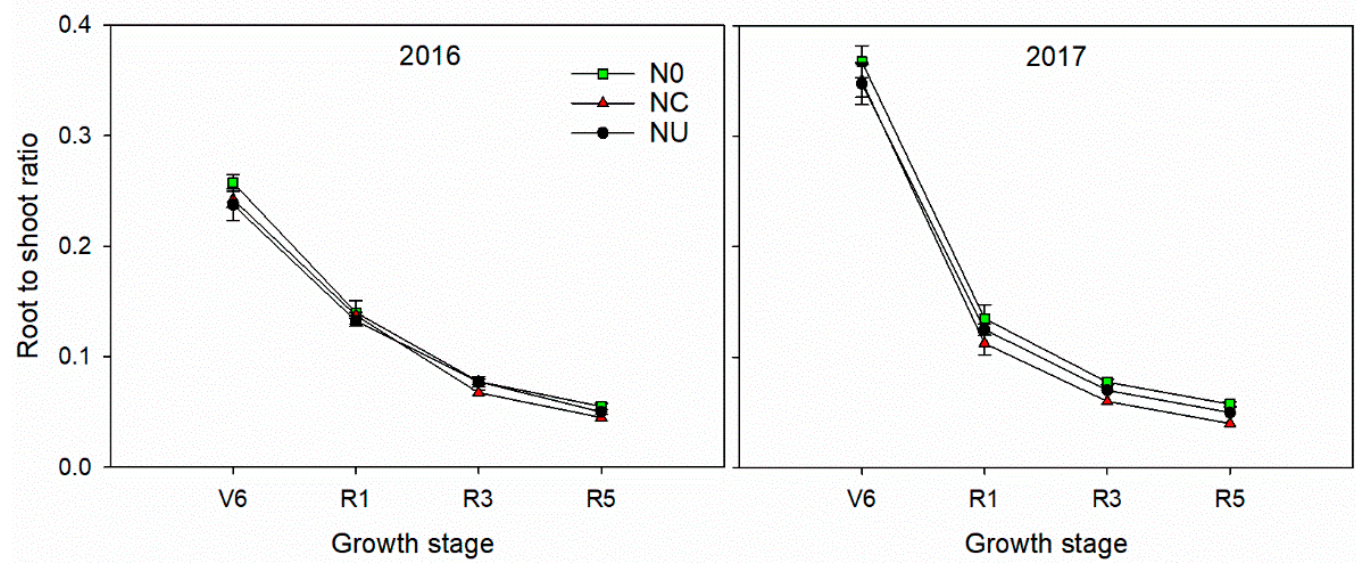

Figure 8. Root to shoot ratio over the entire growing season with the three treatments in 2016 and 2017 as follows: no N application (N0), combined controlled release urea and normal urea at a ratio of 1:2 $(\mathrm{NC})$, and normal urea alone (NU).

\subsection{Correlation Analysis}

We next analyzed the correlations between root parameters (root length density and root weight density) over various soil depths with different maize growth stages under the three $\mathrm{N}$ application treatments and maize grain yields (Table 3). No obvious correlation was found between grain yield and RLD at the V6 stage in 2016 and 2017. At the R1 stage, the grain yields in both years were significantly positively correlated with RLD in the $0-20 \mathrm{~cm}$ soil layer. However, negative correlations were found in the $60-80 \mathrm{~cm}$ soil layer in 2016 and $80-100 \mathrm{~cm}$ soil layer in 2017. At the R3 and R5 stages, grain yields 
exhibited positive correlations with RLD across whole soil profiles in both years (except 20-40 cm at the R5 stage in 2016, as well as 20-40 and 80-100 cm at the R3 stage in 2017).

Table 3. Correlation coefficients between root parameters (root length density (RLD) and root weight density (RWD)) over various soil depths with different growth stages under three $\mathrm{N}$ application treatments and maize grain yields.

\begin{tabular}{|c|c|c|c|c|c|c|c|}
\hline Year & Root Parameters & Growth Stage & $0-20 \mathrm{~cm}$ & $20-40 \mathrm{~cm}$ & $40-60 \mathrm{~cm}$ & $60-80 \mathrm{~cm}$ & $80-100 \mathrm{~cm}$ \\
\hline \multirow{8}{*}{2016} & \multirow{4}{*}{ RLD } & V6 & 0.389 & 0.046 & 0.081 & - & - \\
\hline & & R1 & $0.585 *$ & 0.494 & 0.135 & -0.275 & 0.191 \\
\hline & & R3 & $0.865 * * *$ & $0.891^{* * *}$ & $0.646 *$ & 0.740 ** & $0.718^{* *}$ \\
\hline & & R5 & $0.844^{* *}$ & 0.572 & $0.700 *$ & $0.798^{* *}$ & $0.669 *$ \\
\hline & \multirow{4}{*}{ RWD } & V6 & 0.379 & 0.445 & 0.245 & - & - \\
\hline & & R1 & $0.895^{* * *}$ & $0.832 * *$ & -0.126 & $-0.808^{* *}$ & 0.135 \\
\hline & & R3 & $0.939 * * *$ & $0.938 * * *$ & $0.948^{* * *}$ & $0.882 * * *$ & $0.819 * *$ \\
\hline & & R5 & $0.971^{* * *}$ & $0.954^{* * *}$ & 0.643 * & 0.413 & 0.537 \\
\hline \multirow{8}{*}{2017} & \multirow{4}{*}{ RLD } & V6 & -0.148 & 0.236 & -0.471 & - & - \\
\hline & & R1 & $0.922 * * *$ & 0.336 & 0.337 & 0.308 & -0.610 \\
\hline & & R3 & $0.915^{* * *}$ & 0.567 & $0.725 * *$ & $0.797 * *$ & 0.556 \\
\hline & & R5 & $0.922 * * *$ & $0.928^{* * *}$ & $0.820 * *$ & $0.799 * *$ & $0.880 * * *$ \\
\hline & \multirow{4}{*}{ RWD } & V6 & $0.666^{*}$ & 0.207 & -0.335 & - & - \\
\hline & & R1 & $0.969 * * *$ & 0.512 & -0.229 & -0.359 & $-0.757^{* *}$ \\
\hline & & R3 & $0.979 * * *$ & 0.547 & $0.763^{* *}$ & $0.687^{*}$ & 0.700 * \\
\hline & & R5 & $0.984^{* * *}$ & $0.929 * * *$ & $0.692 *$ & $0.663 *$ & $0.757^{* *}$ \\
\hline
\end{tabular}

N0: no N application, NC: combined controlled release urea and normal urea at a ratio of 1:2, NU: normal urea alone. * significant at $p<0.05 ;{ }^{* *}$ significant at $p<0.01 ; * * *$ significant at $p<0.001$.

The correlations between maize grain yields and RWD showed a similar trend with those of RLD. At the R1 stage, the grain yields were significantly positively correlated with RWD in 0-20 and $20-40 \mathrm{~cm}$ soil layer in 2016 and $0-20 \mathrm{~cm}$ soil layer in 2017. However, significant negative correlations were found in $60-80 \mathrm{~cm}$ soil layer in 2016 and in $80-100 \mathrm{~cm}$ soil layer in 2017 . At R3 and R5 stages, grain yields exhibited positive correlations with RWD across whole soil profiles in both years (except $60-80$ and $80-100 \mathrm{~cm}$ at the R5 stage in 2016 and $20-40 \mathrm{~cm}$ at the R3 stage in 2017).

\section{Discussion}

Root systems have a major impact on the uptake of water and nutrients in crops worldwide. Soil water and nutrients also play a dominant role in root growth and root system architecture [32,33]. Higher RLD provides an advantage for absorbing much more soil water [34]. Strong relationships between RLD and the depletion of soil water have been reported in different plants $[35,36]$. However, excessive $\mathrm{N}$ application may reduce root biomass and suppress root penetration towards the deep soil layer [37,38]. In previous agriculture practices, reducing the amount of $\mathrm{N}$ and adjusting the topdressing ratio were widely used to enhance crop yield and plant $\mathrm{N}$ uptake. Compared to conventional $\mathrm{N}$ fertilizers, using a controlled release fertilizer has been reported as a practice to maintain the grain yield and save labor. In our study, compared with the NU treatment, the NC treatment significantly increased RLD and RWD in the $0-10 \mathrm{~cm}$ soil layer at the R1 stage. This was mainly due to the fact that NC treatment provides relatively excessive $\mathrm{N}$ in the early maize growth stage and $\mathrm{N}$ is no longer a limiting factor [2,39]. Therefore, the NC treatment improved plant growth and induced root distributed in the topsoil in the early growth stage.

Adequate $\mathrm{N}$ promotes above-ground growth, increasing the need for roots to absorb a lot of water and N from deeper soil layers. Therefore, the NC treatment increased the RLD and RWD in the deep soil layers at the R5 stage. Similar results were also reported by Hu et al. [40], who found that controlled release urea induced deeper root growth. As a result, the soil absorbed a lot of water [41], which was consistent with the much lower SWS under NC treatment at the R5 stage. Elevated water use in the deep soil layer may in turn promote the root system in the deep soil layer [2]. The above-ground 
parts of the plant are more likely to be affected by changes in environmental conditions than the root system [42-44]. The NC treatment enhanced root growth to absorb soil water and nutrients, increased dry matter transfer, promoted shoot growth, and eventually decreased R/S. However, the R/S with N0 treatment was not significantly higher than that with NU treatment because of a serious lack of $\mathrm{N}$. This might be explained by the fact that severe $\mathrm{N}$ or water deficiency limited photosynthetic product transport from shoots to roots [38]. The decrease in the R/S might be characteristic of crop evolution. Previous research has suggested that lowering the R/S improves the wheat yield and that the use of a small $R / S$ wheat breed for cultivation in arid and semi-arid areas is important to enhance drought-resistance [45].

Our results also showed that root diameters were smaller in the NC treatment than that in the NU and N0 treatments at the R5 stage, which suggested that combined controlled release urea and normal urea with one-off application may promote the production of fine roots. Thinner root was another important index on the roots' ability to penetrate soil [46], and thus took up much water in the deep soil layer [47]. Some works have already reported that the deeper root distribution is a key characteristic of the ideotype maize root architecture for the absorption of water throughout the entire soil strata, which was beneficial to delay root senescence and improve grain yield $[39,42,48]$. Our study indicated that the NC treatment might be a good choice for inducing the formation of deep root systems to improve deep soil water use efficiency and achieve this goal of high grain yield in arid and semi-arid areas.

Crop grain yield is closely related to root growth and development in the soil. A previous study reported that the wheat grain yield was positively correlated with the RWD in the 20-40 and 40-60 cm soil layer at the jointing stage, and in most soil layers at flowering and maturity stages [49]. It also has been reported that the upper root system has a greater effect on the crop yield than the lower root system [50]. In our study, the maize grain yield showed obvious positive correlations with RLD and RWD in the upper soil layer and negative correlations with RLD and RWD in the deep soil layer at the R1 stage in both years. This finding indicated that at the R1 stage-which is a crucial period for maize grain yield - root development in the upper soil layer is beneficial to the generation of a high yield, and the roots in deeper soil layers at the R1 stage may result from water related stress [49]. The proliferation of roots in deep soil layers consumes photosynthetic product to impact crop yields in the early growth stage [42]. At the R3 and R5 stage, the grain yield showed obvious positive correlations with RLD and RWD in the whole soil profile in both years. This might be because larger contact areas between roots and soil enhance nutrient and water capture by the plant. Our findings support the conclusions of other studies that the root systems across entire soil profiles increase grain yield [51].

It has been reported that the NU treatment, as a traditional high-yield fertilization mode, can achieve high yields while reducing nitrogen loss [7,52]. However, split $\mathrm{N}$ application might be accompanied by a high risk of increasing $\mathrm{N}_{2} \mathrm{O}$ emissions and nitrogen loss which cannot be controlled in rainfed production systems with relatively strong and frequent precipitation in some growth periods [7]. Our study showed that the NC treatment did not overcome the shortcomings of oversupply in early growth stages, but it did solve the problem of $\mathrm{N}$ insufficiency supply in later growth stages compared to the NU treatment. Urea is readily transformed into nitrate with appropriate soil temperature and moisture for crop growth [42]. The application of $2 / 3$ urea could support the growth of maize during the early growth stage and $1 / 3$ controlled release urea could support the growth of maize during the later growth stages, which is consistent with previous research [53]. Although the price of urea is low, the cost of topdressing is high, and the high cost but labor saving feature of the NC treatment might be a tradeoff in terms of practical production $[54,55]$. Our previous study showed that the NC treatment obtained higher net return than the NU treatment $[56,57]$. Therefore, the NC treatment might be a better $\mathrm{N}$ application type, which increased root distribution in the deep soil layer and improved the use of deep soil water in the arid and semi-arid climate of the Loess Plateau. However, considering 
the fluctuating precipitation in the Loess Plateau, the effect of controlled release urea and normal urea mixture on root growth and yield needs to be further studied.

\section{Conclusions}

The results of this study show that NC treatment is more effective at promoting root growth during the whole growth period. It is also more effective at producing fine roots and inducing root proliferation in the deep soil layer during maize's late growth period. The SWS at the R5 stage was lower in the NC treatment, indicating the extractability of water from deeper soil layers by roots in the late growth period in this region was improved. A Positive correlation between the grain yield and the RLD and RWD in the top soil layer at the R1 stage and in the whole soil profiles at the R3 and R5 stages was observed, implying that improved rooting systems and thus greater soil water extraction may contribute to the yield increase with a mixture of controlled release urea and normal urea in arid and semi-arid areas of the Loess Plateau.

Author Contributions: Conceptualization, S.L. and Y.S.; software, L.T.; formal analysis, L.T.; investigation, L.T., H.S., R.S., Y.N., J.S.; data curation, L.T.; writing—original draft preparation, L.T.; writing-review and editing, L.T.; supervision, Y.S.; project administration, Y.S.; funding acquisition, Y.S. All authors have read and agreed to the published version of the manuscript.

Funding: This research was funded by the National Key Research and Development Program (2017YFD0201807), the National Natural Science Foundation of China (41671307, 51279197), the Natural Science Basic Research Plan in Shaanxi Province of China (2017JM3011), and the Open Fund of the State Key Laboratory of Soil Erosion and Dryland Farming on the Loess Plateau (A314021403-C4).

Acknowledgments: We thank the editor and reviewers for insightful comments and suggestions regarding this paper.

Conflicts of Interest: The authors declare no conflict of interest.

\section{References}

1. Cassman, K.G.; Dobermann, A.; Walters, D.T.; Yang, H. Meeting cereal demand while protecting natural resources and improving environmental quality. Annu. Rev. Env. Resour. 2003, 28, 315-358. [CrossRef]

2. Liu, W.X.; Ma, G.; Wang, C.Y.; Wang, J.R.; Lu, H.F.; Li, S.S.; Feng, W.; Xie, Y.X.; Ma, D.Y.; Kang, G.Z. Irrigation and nitrogen regimes promote the use of soil water and nitrate nitrogen from deep soil layers by regulating root growth in wheat. Front. Plant Sci. 2018, 9, 32. [CrossRef] [PubMed]

3. Klocke, N.L.; Watts, D.G.; Schneekloth, J.P.; Davison, D.R.; Todd, R.W.; Parkhurst, A.M. Nitrate leaching in irrigated corn and soybean in a semi-arid climate. Trans. ASAE 1999, 42, 1621-1630. [CrossRef]

4. Griffis, T.J.; Lee, X.; Baker, J.M.; Russelle, M.P.; Zhang, X.; Venterea, R.; Millet, D.B. Reconciling the differences between top-down and bottom-up estimates of nitrous oxide emission for the U.S. corn belt. Glob. Biogeochem. Cycles 2013, 27, 746-754. [CrossRef]

5. Tian, X.F.; Li, C.L.; Zhang, M.; Li, T.; Lu, Y.Y.; Liu, L.F. Controlled release urea improved crop yields and mitigated nitrate leaching under cotton-garlic intercropping system in a 4-year field trial. Soil Tillage Res. 2018, 175, 158-167. [CrossRef]

6. Grant, C.A.; Wu, R.; Selles, F.; Harker, K.N.; Clayton, G.W.; Bittman, S.; Zebarth, B.J.; Lupwayi, N.Z. Crop yield and nitrogen concentration with controlled release urea and split applications of nitrogen as compared to non-coated urea applied at seeding. Field Crop Res. 2012, 127, 170-180. [CrossRef]

7. Wang, S.J.; Luo, S.S.; Li, X.S.; Yue, S.C.; Shen, Y.F.; Li, S.Q. Effect of split application of nitrogen on nitrous oxide emissions from plastic mulching maize in the semiarid Loess Plateau. Agric. Ecosyst. Environ. 2016, 220, 21-27. [CrossRef]

8. Wang, S.J.; Luo, S.S.; Yue, S.C.; Shen, Y.F.; Li, S.Q. Fate of $15 \mathrm{~N}$ fertilizer under different nitrogen split applications to plastic mulched maize in semiarid farmland. Nutr. Cycl. Agroecosyst. 2016, 105, 129-140. [CrossRef]

9. Azeem, B.; Kushaari, K.Z.; Man, Z.B.; Basit, A.; Thanh, T.H. Review on materials \& methods to produce controlled release coated urea fertilizer. J. Control. Release 2014, 181, 11-21. 
10. Trachsel, S.; Kaeppler, S.M.; Brown, K.M.; Lynch, J.P. Maize root growth angles become steeper under low N conditions. Field Crop Res. 2013, 140, 18-31. [CrossRef]

11. Hunt, D.E.; Bittman, S.; Zhang, H.; Bhandral, R.; Grant, C.A.; Lemke, R. Effect of polymer-coated urea on nitrous oxide emission in zero-till and conventionally tilled silage corn. Can. J. Soil Sci. 2016, 96, 12-22. [CrossRef]

12. Shaviv, A. Advances in controlled-release fertilizers. Adv. Agron. 2001, 71, 1-49.

13. He, X.S.; Liao, Z.W.; Huang, P.Z.; Duan, J.X.; Ge, R.S.; Li, H.B.; Geng, Z.C. Characteristics and performance of novel water-absorbent slow release nitrogen fertilizers. Agric. Sci. China 2007, 6, 338-346. [CrossRef]

14. Noellsch, A.J.; Motavalli, P.P.; Nelson, K.A.; Kitchen, N.R. Corn response to conventional and slow-release nitrogen fertilizers across a Claypan Landscape. Agron. J. 2009, 101, 607-614. [CrossRef]

15. Payne, K.M.; Hancock, D.W.; Cabrera, M.L.; Lacy, R.C.; Kissel, D.E. Blending Polymer-Coated nitrogen fertilizer improved Bermuda grass forage production. Crop Sci. 2015, 55, 2918-2928. [CrossRef]

16. Zheng, W.K.; Zhang, M.; Liu, Z.G.; Zhou, H.Y.; Lu, H.; Zhang, W.T.; Yang, Y.C.; Li, C.L.; Chen, B.C. Combining controlled-release urea and normal urea to improve the nitrogen use efficiency and yield under wheat-maize double cropping system. Field Crop Res. 2016, 197, 52-62. [CrossRef]

17. Guo, J.M.; Xue, J.Q.; Blaylock, A.D.; Cui, Z.L.; Chen, X.P. Film-mulched maize production: Response to controlled-release urea fertilization. J. Agric. Sci. 2017, 155, 1299-1310. [CrossRef]

18. Fageria, N.K.; Moreira, A. The role of mineral nutrition on root growth of crop plants. Adv. Agron. 2011, 110, 251-331.

19. Koevoets, I.T.; Henk, V.J.; Elzenga, J.T.M.; Testerink, C. Roots withstanding their environment: Exploiting root system architecture responses to abiotic stress to improve crop tolerance. Front. Plant Sci. 2016, 7, 1335. [CrossRef]

20. Zhang, X.Y.; Chen, S.Y.; Sun, H.Y.; Pei, D.; Wang, Y.M. Dry matter, harvest index, grain yield and water use efficiency as affected by water supply in winter wheat. Irrig. Sci. 2008, 27, 1-10. [CrossRef]

21. Chilundo, M.; Joel, A.; Wesstrom, I.; Brito, R.; Messing, I. Response of maize root growth to irrigation and nitrogen management strategies in semi-arid loamy sandy soil. Field Crop Res. 2017, 200, 143-162. [CrossRef]

22. Shao, H.; Xia, T.T.; Wu, D.L.; Chen, F.J.; Mi, G.H. Root growth and root system architecture of field-grown maize in response to high planting density. Plant Soil 2018, 430, 395-411. [CrossRef]

23. Dunbabin, V.; Diggle, A.; Rengel, Z. Is there an optimal root architecture for nitratecapture in leaching environments? Plant Cell Environ. 2003, 26, 835-844. [CrossRef] [PubMed]

24. Xue, X.R.; Mai, W.X.; Zhao, Z.Y.; Zhang, K.; Tian, C.Y. Optimized nitrogen fertilizer application enhances absorption of soil nitrogen and yield of castor with drip irrigation under mulch film. Ind. Crop Prod. 2017, 95, 156-162. [CrossRef]

25. Chen, X.C.; Zhang, J.; Chen, Y.L.; Li, Q.; Chen, F.J.; Yuan, L.X.; Mi, G.H. Changes in root size and distribution in relation to nitrogen accumulation during maize breeding in China. Plant Soil 2014, 374, 121-130. [CrossRef]

26. Muñoz-Romero, V.; Benítez-Vega, J.; López-Bellido, R.J.; Fontán, J.M.; López-Bellido, L. Effect of tillage system on the root growth of spring wheat. Plant Soil 2010, 326, 97-107. [CrossRef]

27. Liu, Y.; Gao, M.S.; Wu, W.; Tanveer, S.K.; Wen, X.X.; Liao, Y.C. The effects of conservation tillage practices on the soil water-holding capacity of a non-irrigated apple orchard in the loess plateau, China. Soil Tillage Res. 2013, 130, 7-12. [CrossRef]

28. Ritchie, S.W.; Hanway, J.J.; Benson, G.O. How a Corn Plant Develops; Special Report No. 48; Iowa State University, Cooperative Extension Service: Ames, IA, USA, 1992.

29. Böhm, W. Methods of Studying Root Systems; Springer: Berlin, Germany, 1979.

30. Wang, Y.H.; Hua, W.L.; Zhang, X.L.; Li, L.X.; Kang, G.Z.; Feng, W.; Zhu, Y.J.; Wang, C.Y.; Guo, T.C. Effects of cultivation patterns on winter wheat root growth parameters and grain yield. Field Crop Res. 2014, 156, 208-218. [CrossRef]

31. Koide, R.; Peoples, M. On the nature of temporary yield loss in maize following canola. Plant Soil 2012, 360, 259-269. [CrossRef]

32. Nacry, P.; Bouguyon, E.; Gojon, A. Nitrogen acquisition by roots: Physiological and developmental mechanisms ensuring plant adaptation to a fluctuating resource. Plant Soil 2013, 370, 1-29. [CrossRef] 
33. Wang, Y.; Zhang, X.Y.; Chen, J.; Chen, A.J.; Wang, L.Y.; Guo, X.Y.; Niu, Y.L.; Liu, S.R.; Mi, G.H.; Gao, Q. Reducing basal nitrogen rate to improve maize seedling growth, water and nitrogen use efficiencies under drought stress by optimizing root morphology and distribution. Agric. Water Manag. 2019, 212, 328-337. [CrossRef]

34. Eissenstat, D.M. Costs and benefits of constructing roots of small diameter. J. Plant Nutr. 1992, 15, 763-782. [CrossRef]

35. Wiesler, F.; Horst, W.J. Root growth and nitrate utilization of maize cultivars under field conditions. Plant Soil 1994, 163, 267-277. [CrossRef]

36. Craine, J.M.; Wedin, D.A.; Chapin, F.S.; Reich, P.B. Relationship between the structure of root systems and resource use for 11 North American grassland plants. Plant Ecol. 2003, 165, 85-100. [CrossRef]

37. Comfort, S.; Malzer, G.; Busch, R. Nitrogen fertilization of spring wheat genotypes: Influence on root growth and soil water depletion. Agron. J. 1998, 80, 114-120. [CrossRef]

38. Wang, L.; Li, X.G.; Guan, Z.H.; Jia, B.; Turner, N.C.; Li, F.M. The effects of plastic-film mulch on the grain yield and root biomass of maize vary with cultivar in a cold semiarid environment. Field Crop Res. 2018, 216, 89-99. [CrossRef]

39. Xu, X.; Pang, D.W.; Chen, J.; Luo, Y.L.; Zheng, M.J.; Yin, Y.P.; Li, Y.X.; Li, Y.; Wang, Z.L. Straw return accompany with low nitrogen moderately promoted deep root. Field Crop Res. 2018, 221, 71-80. [CrossRef]

40. Hu, H.Y.; Ning, T.Y.; Li, Z.J.; Han, H.F.; Zhang, Z.Z.; Qin, S.J.; Zheng, Y.H. Coupling effects of urea types and subsoiling on nitrogen-water use and yield of different varieties of maize in northern China. Field Crop Res. 2013, 142, 85-94. [CrossRef]

41. Guo, L.W.; Ning, T.Y.; Nie, L.P.; Li, Z.J.; Lal, R. Interaction of deep placed controlled-release urea and water retention agent on nitrogen and water use and maize yield. Eur. J. Agron. 2016, 75, 118-129. [CrossRef]

42. Mi, G.H.; Chen, F.J.; Wu, Q.P.; Lai, N.W.; Yuan, L.X.; Zhang, F.S. Ideotype root architecture for efficient nitrogen acquisition by maize in intensive cropping systems. Sci. China Life Sci. 2010, 53, 1369-1373. [CrossRef]

43. Zhang, X.Y.; Zhang, X.Y.; Liu, X.W.; Shao, L.W.; Sun, H.Y.; Chen, S.Y. Incorporating root distribution factor to evaluate soil water status for winter wheat. Agric. Water Manag. 2015, 153, 32-41. [CrossRef]

44. Wang, L.L.; Palta, J.A.; Chen, W.; Chen, Y.L.; Deng, X.P. Nitrogen fertilization improved water-use efficiency of winter wheat through increasing water use during vegetative rather than grain filling. Agric. Water Manag. 2018, 197, 41-53. [CrossRef]

45. Ma, S.C.; Li, F.M.; Xu, B.C.; Huang, Z.B. Effect of lowering the root/shoot ratio by pruning roots on water use efficiency and grain yield of winter wheat. Field Crop Res. 2010, 115, 158-164. [CrossRef]

46. Jackson, R.B.; Caldwell, M.M. The timing and degree of root proliferation in fertile-soil microsites for three cold desert perennials. Oecologia 1989, 81, 149-153. [CrossRef] [PubMed]

47. Jia, Q.M.; Chen, K.Y.; Chen, Y.Y.; Ali, A.; Manzoor; Sohail, A.; Fahad, S. Mulch covered ridges affect grain yield of maize through regulating root growth and root-bleeding sap under simulated rainfall conditions. Soil Tillage Res. 2018, 175, 101-111. [CrossRef]

48. Xu, C.L.; Tao, H.B.; Tian, B.J.; Gao, Y.B.; Ren, J.H.; Wang, P. Limited-irrigation improves water use efficiency and soil reservoir capacity through regulating root and canopy growth of winter wheat. Field Crop Res. 2016, 196, 268-275. [CrossRef]

49. Wang, C.Y.; Liu, W.; Li, Q.; Ma, D.; Lu, H.F.; Feng, W.; Xie, Y.X.; Zhu, Y.J.; Guo, T.C. Effects of different irrigation and nitrogen regimes on root growth and its correlation with aboveground plant parts in high-yielding wheat under field conditions. Field Crop Res. 2014, 165, 138-149. [CrossRef]

50. Ling, Q.H.; Ling, L. Root function of different depths and their effects on yield in rice. Sci. Agric. Sin. 1984, 17, 3-11, (In Chinese with English Abstract).

51. York, L.M.; Galindo-Castaneda, T.; Schussler, J.R.; Lynch, J.P. Evolution of US maize (Zea mays L.) root architectural and anatomical phenes over the past 100 years corresponds to increased tolerance of nitrogen stress. J. Exp. Bot. 2015, 66, 2347-2358. [CrossRef]

52. Lu, P.; Zhang, J.W.; Jin, L.B.; Liu, W.; Dong, S.T.; Liu, P. Effects of nitrogen application stage on grain yield and nitrogen use efficiency of high-yield summer maize. Plant Soil Environ. 2012, 58, 211-216. [CrossRef]

53. Farmaha, B.S.; Sims, A.L. The influence of PCU and urea fertilizer mixtures on spring wheat protein concentrations and economic returns. Agron. J. 2013, 105, 1328-1334. [CrossRef] 
54. Hyatt, C.R.; Venterea, R.T.; Rosen, C.J.; McNearney, M.; Wilson, M.L.; Dolan, M.S. Polymer-coated urea maintains potato yields and reduces nitrous oxide emissions in a Minnesota loamy sand. Soil Sci. Soc. Am. J. 2010, 74, 419-428. [CrossRef]

55. Guo, J.M.; Wang, Y.H.; Blaylock, A.D.; Chen, X.P. Mixture of controlled release and normal urea to optimize nitrogen management for high-yielding ( $\left.>15 \mathrm{Mg} \mathrm{ha}^{-1}\right)$ maize. Field Crop Res. 2017, 204, 23-30. [CrossRef]

56. Tang, L.; Zhou, J.X.; Zhai, X.F.; Sun, H.R.; Yue, S.C.; Guo, N.; Li, S.Q.; Shen, Y.F. Response of maize productivity and resource use effciency to combined application of controlled-release urea and normal urea under plastic film mulching in semiarid farmland. Agron. J. 2019, 111, 1-13. [CrossRef]

57. Bai, J.; Li, Y.; Zhang, J.; Xu, F.L.; Bo, Q.F.; Wang, Z.L.; Li, Z.Y.; Li, S.Q.; Shen, Y.F.; Yue, S.C. Straw returning and one-time application of a mixture of controlled release and solid granular urea to reduce carbon footprint of plastic film mulching spring maize. J. Clean. Prod. 2021, 280, 124478. [CrossRef]

Publisher's Note: MDPI stays neutral with regard to jurisdictional claims in published maps and institutional affiliations.

(C) 2020 by the authors. Licensee MDPI, Basel, Switzerland. This article is an open access article distributed under the terms and conditions of the Creative Commons Attribution (CC BY) license (http://creativecommons.org/licenses/by/4.0/). 